\title{
Recent Changes in Handling Bank Failures and Their Effects on the Banking Industry
}

\author{
R. Alton Gilbert
}

W $N$ SOME of its public statements in recent years, the Federal Deposit Insurance Corporation (FDIC) has stressed the objective of promoting market discipline of the risks assumed by banks through the influence of uninsured depositors." The FDIC has attempted to accomplish this by allowing the uninsured depositors of some failed banks to suffer losses. In practice, the cases in which uninsured depositors have been exposed to losses involve relatively small banks. As a consequence, the managers of some relatively small banks claim that they have lost large-denomination deposit accounts to larger banks as large depositors reduce the risk of losing part of their deposits by moving their accounts to relatively large banks. ${ }^{2}$

This paper investigates whether the FDIC's actions in recent years indicate a double standard in the treatment of large depositors at large and small banks. Next, the paper analyzes the effects that such a double standard would have on the operation of the banking system. Finally, it investigates whether depositors now act as though they perceive an increase in the risk of holding large-denomination deposits at small banks over holding them at large banks.

R. Alton Gilbert is an assistant vice president at the Federal Reserve Bank of St. Louis. Laura A. Prives provided research assistance.

Federal Deposit Insurance Corporation (1983) and Isaac (1983).

2Hill and Finn (1984) and King (1984).

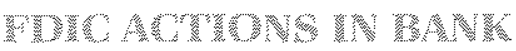

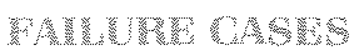

This section presents a brief description of the FDIC's procedures in disposing of the assets and deposit liabilities of insured banks that fail. A knowledge of these procedures is necessary to understand the effect of recent FDIC actions on the risks assumed by large depositors at banks of different size.

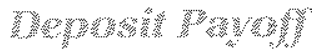

A commercial bank is officially declared a failed bank by its chartering agency - the Comptroller of the Currency for a national bank, the state banking aum thority for a state-chartered bank. The FDIC becomes the receiver of a federally insured bank that fails, with authority to dispose of the assets and to pay off the creditors.

One type of action the FDIC can take as receiver of a failed bank is called a deposit payoff. The FDIC makes payments to each depositor, up to the insumance limit, as soon as the records of deposit accounts can be compiled. Depositors with accounts over the insurance limit become general creditors of the failed bank for the amount of their deposits in excess of the insurance limit. They receive payments on the uninsured portions of their deposits as the FDIC liquidates the assets of the failed bank. Whether they receive full payment on their uninsured deposits depends on the liquidation value of these assets. 


\section{grand}

For the FDIC, there are disadvantages to handling the receivership of a failed bank through a deposit payoff. Banking services are temporarily disrupted, even for the fully insured depositors, who generally must wait a few days to receive their funds. For the uninsured depositors, even if they eventually receive full payment, the delay can throw a wrench into the financing of their activities. Also, the acquisition of the failed bank's assets may be more valuable to another bank than to the FDIC, especially if the other bank could continue to operate the failed bank as a going concern.

The FDIC prefers to handle most bank failure cases through what are called purchase and assumption (P\&A) transactions. In these transactions, all of a failed bank's deposit liabilities are assumed by another bank, which also purchases some of the failed bank's assets. The FDIC initiates a P\&A transaction by soliciting bids from other banks for the purchase of assets and the assumption of deposit liabilities of a failed bank. The FDIC specifies that an interested bank must assume all deposit liabilities and acquire assets considered to be of good value (i.e., excluding loans and debt instruments that are not likely to be paid in full). Additional cash will be provided by the FDIC if the value of the assets of the failed bank offered for purchase is less than the deposit liabilities to be assumed. Banks that are interested in such a package of assets and liabilities bid for it in terms of a purchase premium. The actual cash payment from the FDIC equals the habilities of the failed bank, minus the value of the assets of the failed bank purchased by the bank with the winning bid, less the purchase premium bid by that bank.

In deciding between a deposit payoff or a P\&A transaction, the FDIC uses a cost test. It estimates its cost under both a deposit payoff and a P\&A transaction, based on the bid of the highest purchase premium. The FDIC generally will accept the highest bid for the P\&A transaction if its net cost is lower than the estimated costs of a deposit payoff. These estimates are not very precise, and the FDIC has tended to use the P\&A method except in situations in which:

1. there is virtually no interest by other banks in acquiring the failed bank, or

2. fraud or other circumstances, such as contingent liabilities, make it difficult to estimate losses and, therefore, to apply the cost test. ${ }^{3}$

3Federal Deposit Insurance Corporation (1984), pp. 83-88.

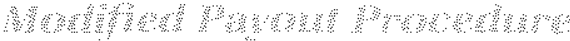

In choosing between a deposit payoff and a P\&A transaction, the FDIC has had to decide which of the following objectives it would give the greatest weight:

1. to avoid disruption of banking services, or

2. to promote market discipline by uninsured depositors of the risks assumed by banks.

If the FDIC tends to handle bank failure cases through deposit payoffs, uninsured depositors must assume the risk of losses if their banks fail. In response, the uninsured depositors might put pressure on their banks to limit risk. But deposit payoffs, as we have seen, disrupt banking services.

The use of $P \& A$ transactions prevents disruptions of banking services. This alternative, however, may give uninsured depositors the impression that they are not exposed to risk of loss when their banks fail. As a consequence, they would not attempt to restrain the risks assumed by their banks.

To avoid the limitations of both procedures, the FDIC announced, in December 1983, that it would use a new procedure for disposing of assets and deposit liabilities in some bank failure cases. The new "modified payout procedure" was adopted to give the FDIC more flexibility in minimizing disruption of banking services, while exposing uninsured depositors to the risk of losses on their deposits. ${ }^{*}$

When a bank failure is handled through the modified payout procedure, the FDIC makes full payments to the insured depositors and partial payments to the large depositors on the uninsured portions of their deposits; the partial payments are based on an FDIC estimate of the proceeds from the liquidation of the assets of the failed bank. If recoveries on the assets eventually exceed the initial estimate, the uninsured depositors receive additional payments; if the proceeds from liquidating those assets fall short of the initial payment, the FDIC absorbs the loss. The partial payment disrupts the activities of uninsured depositors less than the traditional deposit payoff did.

In some cases handled under the modified payout procedure, the insured liabilities of a falled bank are assumed by another bank. This arrangement prevents a disruption of banking services for depositors with full federal insurance. The procedures for arranging this deposit assumption are similar to the procedures in a traditional P\&.A transaction. The FDIC solicits bids

${ }^{4}$ Federal Deposit Insurance Corporation (1983), pp. III-4-III-6. 
for the purchase of some of the assets of the failed bank and the assumption of the fully insured deposit liabilities. The FDIC provides cash to cover a gap between the value of assets purchased and the fully insured deposit liabilities assumed, minus any purchase premium. The FDIC then receives the remaining assets and makes a partial payment to the uninsured depositors. This approach to handling bank failure cases has similarities to both the deposit payoff and $P \& A$ transaction procedures.

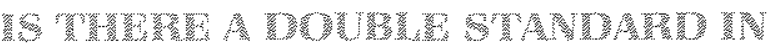

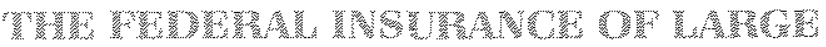

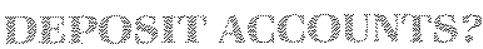

The official limit on deposit insurance coverage, currently the first $\$ 100,000$ for each depositor at each depository institution, is the same for insured banks of all sizes. There is circumstantial evidence, however, that the FDIC provides large depositors at a few of the nation's largest banks greater protection from loss than large depositors at smaller banks. There is no official statement of this double standard by the FDIC; if it exists, it must be inferred from the FDIC's actions in bank failure cases.

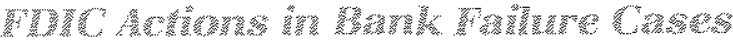

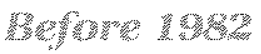

Until 1982, every bank failure involving assets greater than $\$ 100$ million had been handled through $P \& A$ transactions, thus protecting the uninsured depositors from any losses. ${ }^{.}$From 1968, when the FDIC adopted its current procedures for P\&A transactions, through 1981, only 32 of the 108 bank failure cases were handled through deposit payoffs. These 32 banks, which had average total assets of $\$ 10.4$ million, had relatively few deposit accounts in excess of the insurance limit. The other 76 had average total assets of $\$ 171$ million." These FDIC actions could have convinced most large depositors that, in effect, they had complete insurance coverage of their deposit accounts, even if their accounts exceeded the officially stated insurance limit.

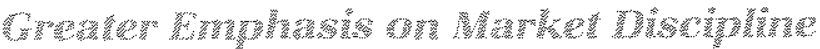

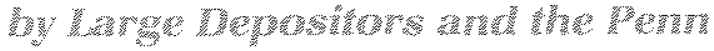

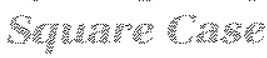

In the early $1980 \mathrm{~s}$, the FDIC became concerned

5Federal Deposit Insurance Corporation (1984), p. 93.

Glbid., table 4-2, p. 65. about a lack of market discipline imposed by large depositors on the risks assumed by their banks. This concern was stimulated by the view that various forms of deregulation gave bankers greater freedom to assume more risk.

The response of the FDIC to the failure of the Penn Square Bank of Oklahoma City in 1982 reflected, in part, an intention to increase the degree of market discipline by large depositors. The FDIC closed the Penn Square Bank, which had total assets of $\$ 517$ million, and paid off each depositor up to the federal insurance limit.

A recent history of the FDIC mentions two reasons for closing the Penn Square Bank and paying off the depositors, rather than protecting the uninsured depositors through a $P \& A$ transaction. First, it was not possible at that time for the FDIC to determine the costs of alternative methods of handling the case. Second, the FDIC was concerned that, if the large depositors of the Penn Square Bank were protected from losses, market discipline of the risks assumed by banks through the influence of large depositors would be eroded. The FDIC concluded that paying off the depositors of the Penn Square Bank, up to the insurance limit, and allowing the uninsured depositors to suffer losses, would cause investors to perceive a greater risk in holding large-denomination deposits. ${ }^{\text {s }}$

The handling of the Penn Square case indicated that, in order to promote market discipline by large depositors, the FDIC was willing to apply the deposit payoff procedure in the failure of a much larger bank than it had in the past. This case did not reveal, however, whether the FDIC would put a limit on the size of a failed bank that would be handled through a deposit payoff. Thus, the FDIC's actions in this case did not indicate whether the risks of holding large deposit accounts had risen more for those with accounts at small banks or large banks.

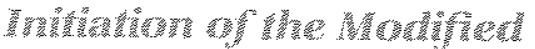

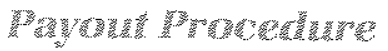

The next major action by the FDIC to induce uninsured depositors to restrain the risks assumed by their banks was the adoption of the modified payout procedure. As mentioned above, an important objective for adopting this procedure was to expose uninsured

This concern about a lack of market discipline is expressed in Federal Deposit Insurance Corporation (1983).

aFederat Deposit Insurance Corporation (1984), pp. 97-98. 
depositors to some risk of loss if their banks fail, while minimizing the disruption to banking services.

The first bank failures handled under the modified payout procedure occurred in March 1984. From March through May 1984, the FDIC used the new modified payout procedure in nine bank failure cases. In two of those cases, the banks were closed and the FDIC made payments to all depositors. The only difference between these two cases and the usual deposit payoff case was that the uninsured depositors received partial payments when their banks were closed, instead of receiving any payments after the FDIC liquidated the assets.

In the other seven cases handled under the modified payout procedure, other banks assumed the fully insured deposit liabilities of the failed banks and pur. chased some of their assets. Since other banks were interested in bidding for the assets and fully insured deposit liabilities of these seven banks, it is likely that their uninsured depositors would also have been protected from losses through P\&A transactions if the FDIC had not adopted the modified payout procedure.

All of the seven bank failure cases handled under the modified payout procedure, with assumption of fully insured deposit liabilities by other banks, involved relatively small banks. The total deposits of those seven banks ranged from $\$ 16$ million to $\$ 116$ million, with a mean of $\$ 54$ million. Their uninsured deposits on average were $\$ 1.6$ million.

\section{The Crow}

The rapid withdrawal of foreign deposits from the Continental Illinois National Bank, Chicago, created a financial crisis for that bank in May 1984. The FDIC, the Federal Reserve, and the Comptroller of the Currency became concerned about the effects that the failure of Continental would have on other depository institutions and economic activity in general. These agencies issued a joint news release on May 17, 1984, that described a program of assistance for Continental. That joint news release includes the following statement:

In view of all the circumstances surrounding Continental Hlinois Bank, the FDIC provides assurance that, in any arrangements that may be necessary to achieve a permanent solution, all depositors and other general creditors of the bank will be fully protected and services to the bank's customers will not be interrupted.

This statement indicates that, although the FDIC wishes to induce large depositors to restrain the risks assumed by their banks, there is an upper limit on the size of banks at which large depositors are subject to losses.

From June 1984 through May 1985, the FDIC handled six more bank failure cases by arranging for the assumption of the fully insured deposit liabilities by other banks, but limiting payments on uninsured deposits to the proceeds from liquidating the assets of the failed uanks. Total deposits of those six banks range between $\$ 4$ million and $\$ 46$ million la mean of $\$ 26$ million, with average uninsured deposits of about $\$ 400,000 . "$

\section{A Hor

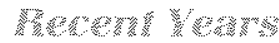

The actions of the FDIC since mid 1982 reveal the following pattern: To promote market discipline by large depositors, the FDIC is willing to close a failing bank with total assets as large as $\$ 500$ million. In practice, the modified payout procedure, which was adopted to promote market discipline by large depositors, has been used in the failure of a few relatively small banks. Banks as large as Continental Illinois appear to be exempt from this policy. This combination of FDIC actions may imply that the risk of holding deposits in an account that exceeds the federal insurance limit has increased in recent years, unless that account is at one of the largest banks in the nation.

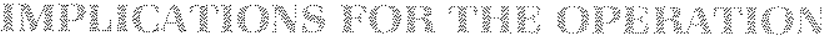 OW W}

If large depositors think they are protected from losses by holding their funds at relatively large banks, they will have no incentive to monitor the risks assumed by these banks or to put pressure on the management of these banks to restrain risks. Thus, by protecting depositors at relatively large banks from losses, the FDIC may have reduced the restraints on risks assumed by relatively large banks.

Actions that favor uninsured depositors at relatively large banks also may have implications for trends in the nation's banking structure. The share of the nation's banking assets at a few of the relatively large banks may rise over time, as large depositors shift their funds to the relatively large banks to reduce risks.

In some of these six cases, the large depositors did not receive partial payments when the banks failed, because it was difficult for the FDIC to estimate fecovery on the assets it assumed. 
WA

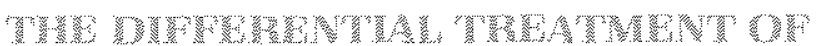

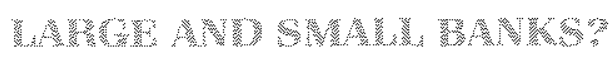

Before concluding that the recent actions of the FDIC in bank failure cases have the implications for the banking system discussed above, one must determine whether depositors have responded to what appears to be differential treatment of large and small banks. There are various reasons why the events de scribed above might not affect the behavior of uninsured depositors. Large depositors may have believed for some time that the FDIC would not allow a bank the size of Continental llinois to fail. The FDIC had acted in the past to prevent the failure of relatively large banks with total assets smaller than those of Continental." Thus, the announcement of the deposit guarantee for Continental in May 1984 may have come as no surprise.

Alternatively, holders of uninsured deposits may continue to have confidence in their own banks despite the increased risk of keeping their accounts at small banks. Or, they might not be aware of the implications of FDIC actions in recent bank failure cases.

There are two potential pieces of evidence that would support the view that depositors consider the risk of holding uninsured deposits at small banks to have risen relative to the risk of holding deposits of similar size at large banks. First, interest rates that small banks offer to attract large-denomination deposits must rise relative to the interest rates offered by large banks. Second, the share of total time deposits at all commercial banks in accounts above the insurance limit must rise at relatively large banks and decline at small banks, as depositors shift their large-denomination deposit accounts to relatively large banks. Both of these patterns would have to begin after mid-May 1984, when the FDIC announced the deposit guarantee of Continental lllinois Bank.

\section{W}

Data on the interest rates paid on largedenomination time deposits are not available for relatively small banks. Consequently, the observations are limited to those for the allocation of large time deposits among large and small banks.

10See the Federal Deposit Insurance Corporation (1984), pp. 89-97.

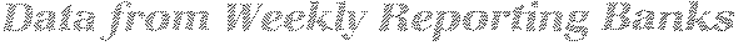

There is no official list of banks that are too large to fail. As an approximation to the group of banks that may have such status, this paper uses the 30 largest banks in the nation." Small banks are identified as those smaller than weekly reporting banks (which include all commercial banks with total assets of $\$ 1.4$ billion or more as of December 31, 1982).

Chart 1 does not indicate a sustained pattern of decline in the share of large-denomination time de posits at small banks or a rise in the share at relatively large banks after mid-May 1984. The share of largedenomination time deposits at the small banks did decline from almost 40 percent in the first week of May 1984 to about 37 percent in the last week in June of last year. That change might reflect an initial response by depositors to the handling of the Continental Illinois situation by the FDIC. In contrast, that decline might reflect a seasonal pattern; the share of largedenomination time deposits at small banks declined between the same weeks in 1982. Whatever the cause of that dip, it was more than reversed by October of last year, and the share of large time deposits at small banks continued to rise through May 1985 . The share of large-denomination deposits at small banks declined in June 1985 , as it had in June of 1982 and $19844^{\text {I: }}$

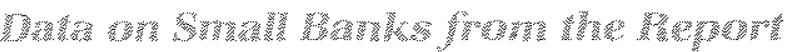

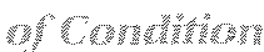

Observations in chart 1 may suffer from several measurement problems. First, the banks with total assets just below $\$ 1.4$ billion are included together with much smaller banks. A finer breakdown of banks by asset size may be necessary to detect an outflow of large-denomination time deposits from small banks.

Second, some of the time deposits in denominations of $\$ 100,000$ or more are in accounts of exactly

\footnotetext{
"In September 1984, the Comptroller of the Currency, C.T. Conover, was reported in the press as saying that the federal regulators would not allow the largest 11 banks to fail; later, however, he denied stating any cut-off figure for banks too large to fail. See Trigaux (1984).

12The patterns in chart 1 reflect differential eftects of the authorization of money market deposit accounts (MMDAs) at large and small banks. Large time deposits at all commercial banks declined sharply after the announcement that MMDAs would be available in midDecember 1982. These deposits had peaked in October 1982, but by May 1983 , had declined by about $\$ 50$ billion. During the same period, large time deposits at small banks rose by about $\$ 13$ billion. Thus, the small banks do not seem to have been affected by the substitution between large-denomination deposits and MMDAs in the same way as the larger banks.
} 


\section{Chart 1 \\ Share of Large-Denomination Time Deposits at Large and Small Banks}

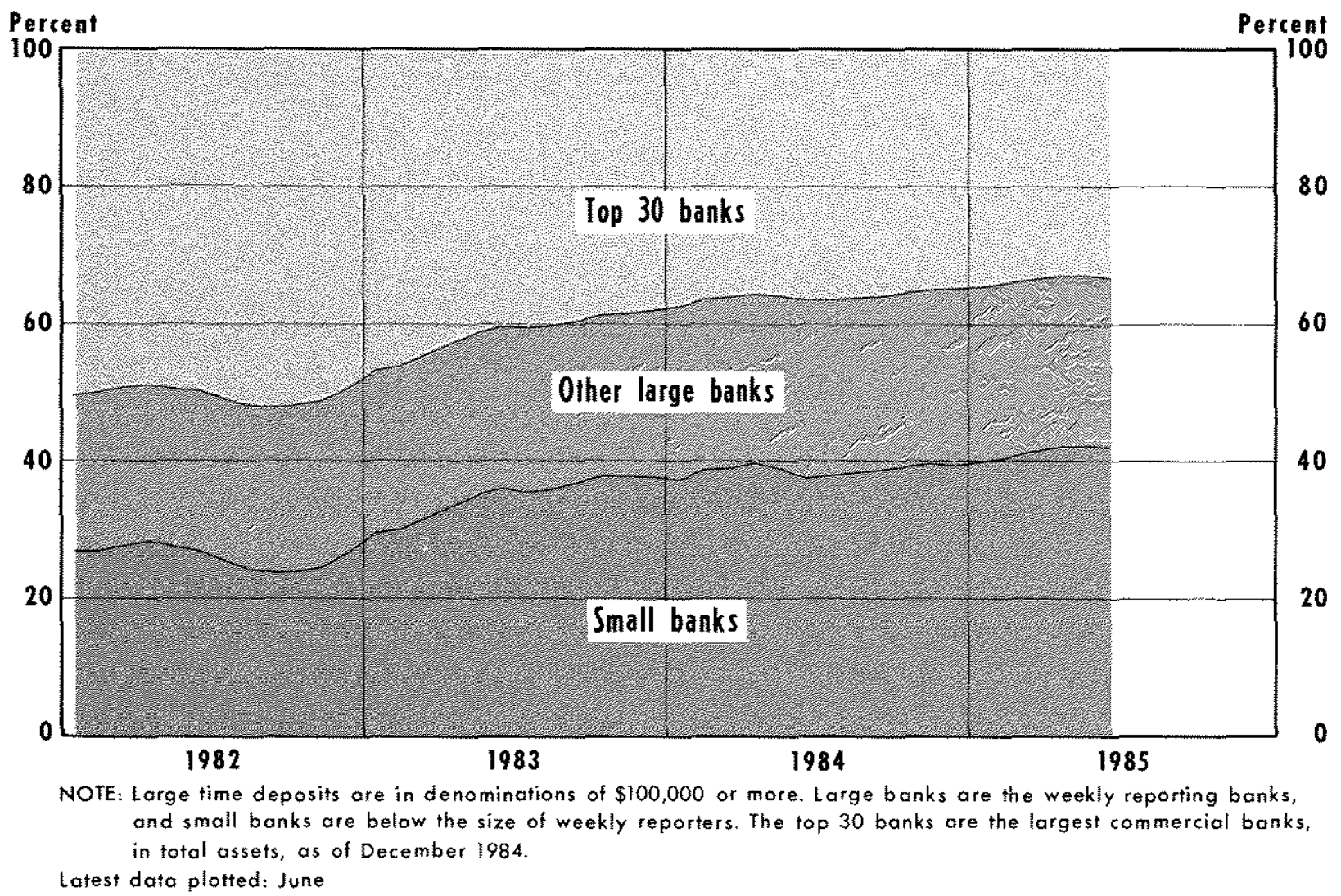

$\$ 100,000$, and, therefore, are fully insured. Thus, the percentage of time deposits in denominations of $\$ 100,000$ or more overstates the percentage of time deposits in accounts that are only partially insured.

The third possible measurement problem is that many of the small banks are subsidiaries of large banking organizations. Uninsured depositors may be less concerned about possible losses of their deposits at a relatively small bank if it is a subsidiary of a large banking organization.

The relevance of these possible measurement problems can be investigated with data from the Report of Condition of each commercial bank. Table 1 presents the percentage of large-denomination time deposits in the banking system at groups of relatively small banks in various size categories. To eliminate banks that are subsidiaries of relatively large banking organi- zations, the banks in table 1 are in organizations with total banking assets less than $\$ 1$ billion.

The issue of which large-denomination time deposits are only partially insured is more difficult to settle. In attempting to exclude time deposits in denominations of $\$ 100,000$ or more that are fully insured, the best approach available with the existing data is to exclude from the calculations those banks with brokered deposits in denominations of $\$ 100,000$ or less, which are called "retail brokered deposits." Deposit brokers typically break down the funds they place at an individual bank into units of $\$ 100,000$ or less for their individual investors, so that the deposits of each investor are fully insured. The banks with retail brokered deposits, therefore, are the ones likely to have the largest proportion of time deposits in denominations of exactly $\$ 100,000$. 
Table 1

Percentage of Large-Denomination Time Deposits in Various Size Banks'

\begin{tabular}{|c|c|c|c|c|c|c|}
\hline \multirow{2}{*}{$\begin{array}{l}\text { Brnk size otegory } \\
\text { (millions of ololars) }\end{array}$} & \multirow{2}{*}{ Number } & \multicolumn{4}{|c|}{1984} & \multirow{2}{*}{$\begin{array}{l}10 \mathrm{~s} \\
\mathrm{Nonch}\end{array}$} \\
\hline & & march & une & September & December & \\
\hline Under $\$ 10$ & 422 & $014 \%$ & $015 \%$ & $016 \%$ & $017 \%$ & $0,19 \%$ \\
\hline$\$ 101025$ & 1,450 & 1,13 & 14 n & 118 & 121 - & 133 \\
\hline$\$ 251050$ & 1,464 & 260 & 258 & 2,64 & 266 & 280 \\
\hline$\$ 5010100$ & 866 & 394 & 389 & 390 & 393 & 428 \\
\hline$\$ 10010300$ & 584 & 5,63 & 563 & 580 & 579 & 6,1 \\
\hline$\$ 300$ 10 500 & 93 & 237 & 238 & 246 & 2,45 & 250 \\
\hline$\$ 500101,000$ & 60 & 233 & 236 & 2,40 & 253 & 259 \\
\hline স & 5009 & 1814 & $18 \times 3$ & 1662 & 1874 & 1989 \\
\hline
\end{tabular}

The same banks are noluded in each ske group as of each of he fve repon ot oonditondates. As of each date these banks repolted ho retalb bokered deposits. These banks are assigned to the same size group as of each date based on their total assets as of March 1984 .

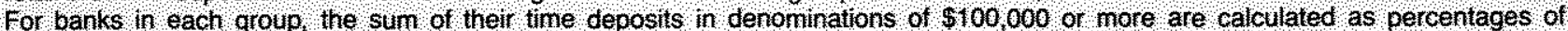
large denominalion time deposits as of the same date at all commercla banks that lepolted no retall brokered deposiss

Table 2 provides indirect evidence on the extent to which the time deposits in denominations of $\$ 100,000$ or more exceed the insurance limit at banks with no retail brokered deposits. The FDIC collected data through June 1981 on various types of deposit accounts that exceeded the insurance limit. As of June 1981, the percentages of time deposits in denominations of $\$ 100,000$ or more are only slightly higher than the percentages in accounts that exceeded the insurance limit. Thus, as of June 1981, very high percentages of time deposits in denominations of $\$ 100,000$ or more were only partially insured. Also, for banks of comparable size, the percentages of time deposits in denominations of $\$ 100,000$ or more in June 1984 are similar to the percentages in June 1981. These comparisons of observations in table 2 provide a basis for concluding that high percentages of the time deposits in denominations of $\$ 100,000$ or more, as of June 1984 , were only partially insured. Data are not available, however, to provide direct evidence on this issue.

Data on retail brokered deposits for all federally insured commercial banks are not available before March 1984. Beginning with the quarterly Report of Condition in March 1984, each bank reports the total dollar amount of all brokered deposits and of retail brokered deposits. Data based on the Report of Condition, therefore, are limited to the period since March 1984.

The purpose of the calculations presented in table 1 is to determine whether banks in various size groups have increased or decreased their share of largedenomination time deposits in the banking system. Banks in each of the size groups have the following characteristics: First, each bank filed a Report of Condition on all five dates. Second, each bank reported no retail brokered deposits on each date. Third, each bank is assigned to one size class for all five dates, based on its total assets as of March 1984. Thus, each size group includes the same banks for each of the Report of Condition dates.

The numerator of each percentage in table 1 is the sum of time deposits in denominations of $\$ 100,000$ or more for a given group of banks, as of a Report of Condition date. The denominator is the sum of largedenomination time deposits of all commercial banks as of the same date, excluding those banks that reported retail brokered deposits.

As of March 1984, these 5,039 banks accounted for about 18 percent of large-denomination time deposits of the banking system. By March 1985, that percentage rose to almost 20 percent, and the share of largedenomination time deposits rose for each of the seven groups of banks. Thus, the evidence in chart 1 and table 1 are consistent: the share of largemdenomination time deposits at relatively small banks is higher in early 1985 than a year earlier, before the announcement of the federal guarantee of all deposit liabilities at the Continental Illinois bank. 


\section{Table 2}

\section{Average Percentages of Time Deposits in Large-Denomination Accounts}

\begin{tabular}{|c|c|c|c|}
\hline \multirow{2}{*}{$\begin{array}{l}\text { Bank size } \\
\text { category } \\
\text { (millons of } \\
\text { dollars of } \\
\text { total deposits) }\end{array}$} & \multirow{2}{*}{$\begin{array}{l}\text { Percentage of } \\
\text { time deposits } \\
\text { In accounts } \\
\text { larger than } \\
\$ 100,000, \\
\text { June } 1981 \text {, }\end{array}$} & \multicolumn{2}{|c|}{$\begin{array}{l}\text { Percentage of time deposits } \\
\text { in accounts of } \\
5100,000 \text { or more }\end{array}$} \\
\hline & & June 1981 & June 1984 \\
\hline Under $\$ 10$ & $149 \%$ & $172 \%$ & $211 \%$ \\
\hline 8101025 & 169 & 182 & 208 \\
\hline$\$ 251050$ & 20.4 & 214 & 227 \\
\hline$\$ 5010100$ & 25.6 & 269 & 266 \\
\hline$\$ 100 \div 0500$ & 348 & 373 & 341 \\
\hline$\$ 500101,000$ & 432 & 46.6 & 367 \\
\hline
\end{tabular}

The numeraters and denominators of these percentages include time deposts of individuals, partnerships, and corporations and public funds invested in time and savings deposits at commerciat banks.

Banks included in the calculations lor June 1984 have no retall brokered deposits they are in banking organizations with total banking assets less than $\$ 1$ bilion.

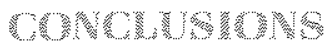

The Federal Deposit Insurance Corporation (FDIC) has been putting greater emphasis in recent years on increasing the incentives for large depositors to restrain the risks assumed by their banks, by allowing the uninsured depositors of some failed banks to suffer losses. FDIC actions designed to promote market discipline by large depositors, however, have affected primarily relatively small banks. In contrast, the FDIC guarantee of all deposit liabilities of the Continental Illinois National Bank in May of last year indicates that the large depositors of a few of the nation's largest banks may have no risk of losses if their banks experience large reductions in the value of their assets.

This contrast in treatment of large and small banks might be expected to induce large depositors to shift their accounts to a few of the nation's largest banks. The data available to test this hypothesis have some limitations. The most appropriate conclusion, given the nature of the data, however, is that large deposi- tors have not shifted their accounts from small to large banks since the announcement of the FDIC guarantee of all deposit liabilities of Continental Illinois.

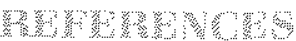

Federal Deposit Insurance Corporation. "Deposit Insurance in a Changing Environment" in A Report to Congress on Federal Deposit insurance (April 1983).

The First Fity Years: A History of the FDIC, 1933-1983 (Washington, D.C., 1984).

Hill, C. Christian and Edwin A. Finn. "Confidence Crisis: Big Deposi" tors' Runs on Beleaguered Banks Speed the Faiture Rate," Wall Street Joumal, August 23, 1984.

Isaac, William M. Address before the Management Conference of the National Council of Savings Institutions, New York, December 6, 1983.

King, A. J. "Treat Smatl Banks, Continental Similarly," American Banker (May 31, 1984), pp. 4, 12.

Trigaux, Robert. "Comptroller Trying to Dispel Reports of 'Guarantees' for Top 11 Banks Only," American Banker (September 28, 1984), p. 3. 